\title{
Seroprevalence and Molecular Biodiversity of Hepatitis B and Delta Virus Infections in the Republic of Congo
}

\author{
A. Mongo-Onkouo ${ }^{1,2}$, R. Itoko Okombi' ${ }^{1}$ A. Boumba ${ }^{2,3}$, F. R. Niama4 ${ }^{4}$ C. P. Ahoui-Apendi',2, \\ J. F. Mimiesse Monamou ${ }^{1,2}$, N. A. Itoua-Ngaporo ${ }^{1,2}$, L. C. Atipo-Ibara Ollandzobo Ikobo ${ }^{2,5}$, \\ Deby Gassaye ${ }^{1,2}$, M. Ngalessami Mouakosso', C. S. Adoua1, B. I. Atipo-Ibara1,2, J.-R. Ibara',2 \\ ${ }^{1}$ Gastro-Enterology and Internal Medicine, CHU of Brazzaville, Brazzaville, Congo \\ ${ }^{2}$ Faculty of Health Sciences, Ngouabi Marien University, Brazzaville, Congo \\ ${ }^{3}$ Laboratory Service Hospital General of Louandjili, Pointe-Noire, Congo \\ ${ }^{4}$ National Public Health Laboratory, Brazzaville, Congo \\ ${ }^{5}$ Infant Pediatric Service, CHU of Brazzaville, Brazzaville, Congo \\ Email: mongoonkouo@gmail.com
}

How to cite this paper: Mongo-Onkouo, A., Itoko Okombi, R., Boumba, A., Niama, F.R., Ahoui-Apendi, C.P., Mimiesse Monamou, J.F., Itoua-Ngaporo, N.A., Atipo-Ibara Ollandzobo Ikobo, L.C., Deby Gassaye, Ngalessami Mouakosso, M., Adoua, C.S., Atipo-Ibara, B.I. and Ibara, J.-R. (2018) Seroprevalence and Molecular Biodiversity of Hepatitis B and Delta Virus Infections in the Republic of Congo. Open Journal of Gastroenterology, 8, 448-454. https://doi.org/10.4236/ojgas.2018.812046

Received: October 23, 2018

Accepted: December 24, 2018

Published: December 27, 2018

Copyright (๑) 2018 by authors and Scientific Research Publishing Inc. This work is licensed under the Creative Commons Attribution International License (CC BY 4.0).

http://creativecommons.org/licenses/by/4.0/

\begin{abstract}
Hepatitis B virus (HBV) infection is a major public health problem in the world. In Congo, studies on the prevalence of HBV infection are common but HDV infection is rare. Objective: Contribute to improve the management and prevention of HBV and HDV infections. Patients and Methods: This was a descriptive and cross-sectional study conducted from January to August 2016 in the health services of the various departments of Congo and at the national public health laboratory in Brazzaville. All patients with HBsAg surface antigen who were at least 18 years old and who consented to the study were included. The HBs antigen was first tested by a rapid test then confirmed by ELISA. All HBsAg positive patients were subsequently subjected to a second ELISA test for Delta antibody. The techniques of extraction and conventional and specific gene amplification were carried out on plasma for the identification of the genotypes of the two viruses. The data analysis was done with EpiInfo V7 software. The proportions were compared using the Chi-square test or the Fisher test at the significance level of 5\%. Results: 1618 subjects were included, of whom 180 were positive for $\mathrm{HBsAg}$, a frequency of $11.12 \%$. The sex ratio $(\mathrm{M} / \mathrm{F})$ was $0.77 \%$, the mean age was $40.2 \pm 15.6$ years with extremes ranging from 18 to 88 years. Of the $180 \mathrm{HBsAg}$ positive, 22 were anti-VHD positive, a frequency of $12.22 \%$. HBV DNA was amplified in 83.8\% (151/180), HDV RNA in 63.6\% (14/22). For HBV, three genotypes were identified: E (46.9\%), A (43.7\%) and D (9.4\%), however for VHD three genotypes D1, D5, D8 were identified. Conclusion: Co-infection of hepatitis
\end{abstract}


$B$ and Delta viruses is common in Congo. The management and prevention of hepatitis B must take into account the reality of this co-infection.

\section{Keywords}

Seroprevalence, Molecular Biodiversity, Hepatitis B Virus and Delta, Congo

\section{Introduction}

An estimated 350 million people are infected with the hepatitis B virus (HBV), 15 million with the hepatitis D virus (HDV) [1]. HDV is a satellite virus whose expression and multiplication requires the assistance of $\mathrm{HBV}$ and more precisely the presence of the surface antigen of this virus (HBsAg) [2]. About a quarter of the 65 million chronic carriers of HBV are suspected of being infected with HDV [3]. HDV infection can occur in two circumstances: simultaneous infection (co-infection) with both viruses or superinfection with HDV of a chronic carrier of HBV. Co-infection or superinfection may be responsible for fulminant forms or severe chronic course [4]. We distinguish the regions where the superinfection is endemic (southern Italy, Amazon Basin, certain areas of Africa and the Middle East); areas where superinfection is not endemic (North America, Western Europe) [5] [6]. Congo is considered a country of high endemicity of HBV. However, the high frequency of viral hepatitis $B$, the predominance of primary liver cancers in the same population, and the high rate of HBsAg carriers in presumed healthy subjects [5] [6] [7] suggest a high prevalence of HDV in the general population. However, the co-infection of hepatitis B virus and Delta is poorly documented in Congo. It is with this in mind that we have done this work in order to characterize the molecular profile of viral hepatitis B viruses and viral hepatitis $\mathrm{D}$ to help improve patient care.

\section{Patients and Methods}

This was a descriptive and cross-sectional study that ran from January 1 to August 30, 2016, for a period of 8 months. The study was conducted in the Republic of Congo in the Basic Hospitals and Integrated Health Centers (CSI) of the following departments: Likouala, Central basin, Sangha, Lekoumou, Niari, Pointe-Noire and Brazzaville. Serological and molecular analyzes were performed in Brazzaville at the National Public Health Laboratory (LNSP). The choice of health facilities that served as a survey frame was random. Included in our study were all patients, all at least 18 years old, outpatients present in the various localities mentioned above during the study period and who gave their verbal and/or written consent. We excluded patients who have been living for less than one year in the departments concerned, hospitalized patients and those who refused to give their consent.

The following epidemiological variables were studied: age and sex. Biological 
variables were: HBsAg, anti VHD, HBV DNA, HDV RNA, VHB genotype and HDV. The serological analysis was carried out from a sample of $5 \mathrm{ml}$ of blood collected in an EDTA tube. The serological analysis was carried out from a sample of $5 \mathrm{ml}$ of blood collected in an EDTA tube. The tubes were then centrifuged at $5000 \mathrm{rpm} / \mathrm{min}$ for $10 \mathrm{~min}$ to get a clear plasm and in sufficient quantity. After centrifugation, the collected plasma was placed in cryotubes and then stored at $-20^{\circ} \mathrm{C}$. The serological study focused on the detection of HBsAg first by rapid screening test (TROD: rapid diagnostic orientation test) "MICROPOINT". The confirmation was made by ELISA test "Human AgHBs ELISA, Germany" on microplates according to the manufacturer's instructions. All HBsAg positive samples were first tested serologically for anti-HDV antibody by ELISA (kitETI-AB-DELTAK-2, DiaSorin, USA), then extraction of the viral DNA from the “QIAGEN QIamp DNA blood kit” kit for hepatitis B and RNA from the "system invitrogen superscript III RT platinum" kit (Invitrogen) for Delta hepatitis following the manufacturers instructions. Molecular analysis focused on the HBV S surface gene from the following primer pairs:

HBPr1(5'-GGGTCACCATATTCTTGGG-3')/HBPr135[5'-CA(A/G)AGACAAA AGAAAATTGG-3'] and

HBPr2(5'-GAACAAGAGCTACAGCATGGG-3')/HBPr3(5'-CCACTGCATGGC CTGAGGATG-3') using the nested PCR technique [8]. The viral RNA analysis of HDV was done by single-step gene amplification combining a reverse transcript necessary to obtain the complementary DNA and a PCR nested from the complementary DNA obtained. Amplification was done from primer pairs D2(5'-ACAAGGAGAGGCAGGATCACCGAC3')/D3(5'GAGATGCCATGCCG ACCCGAAGAG-3') and

\section{D1(5'-GCCCAGGTCGGACCGCGAGGAGGT-3')/D4(5'GAAGGAAGGCCCT}

CGAGAACAAGA-3') in a TECHNE TC-312 thermocycler [9]. The PCR products were read on a $2 \%$ agarose gel in Tris-Borate-EDTA (TBE) buffer. The PCR products nested with $\mathrm{HBV}$ and $\mathrm{HDV}$ viruses were directly sequenced and the genotypes were identified using the BLAST algorithm by comparing the nucleotide sequences with the GenBank database (NCBI). Positive patients have been referred to specialized hospitals for treatment. The data analysis was done with EpiInfo V7 software. The proportions were compared using the Chi-square test or the Fisher test at the significance level of $5 \%$.

\section{Results}

A total of 1618 patients benefited from samples for HBsAg research. The average age of our study population was $40.2 \pm 15.6$ years with extremes ranging from 18 to 88 years. The distribution of patients by age group is shown in Figure 1. The sex ratio (m/f) was 0.77 . Of the 1618 patients, 180 patients had HBsAg, a seroprevalence of $11.1 \%(180 / 1618)$. Of the 180 patients with HBsAg, 22 patients were positive for anti-HDV, which is a $12.2 \%$ prevalence of hepatitis delta $(22 / 180)$. There were $11(50 \%)$ men and 11 (50\%) women, the sex ratio was 1 , 


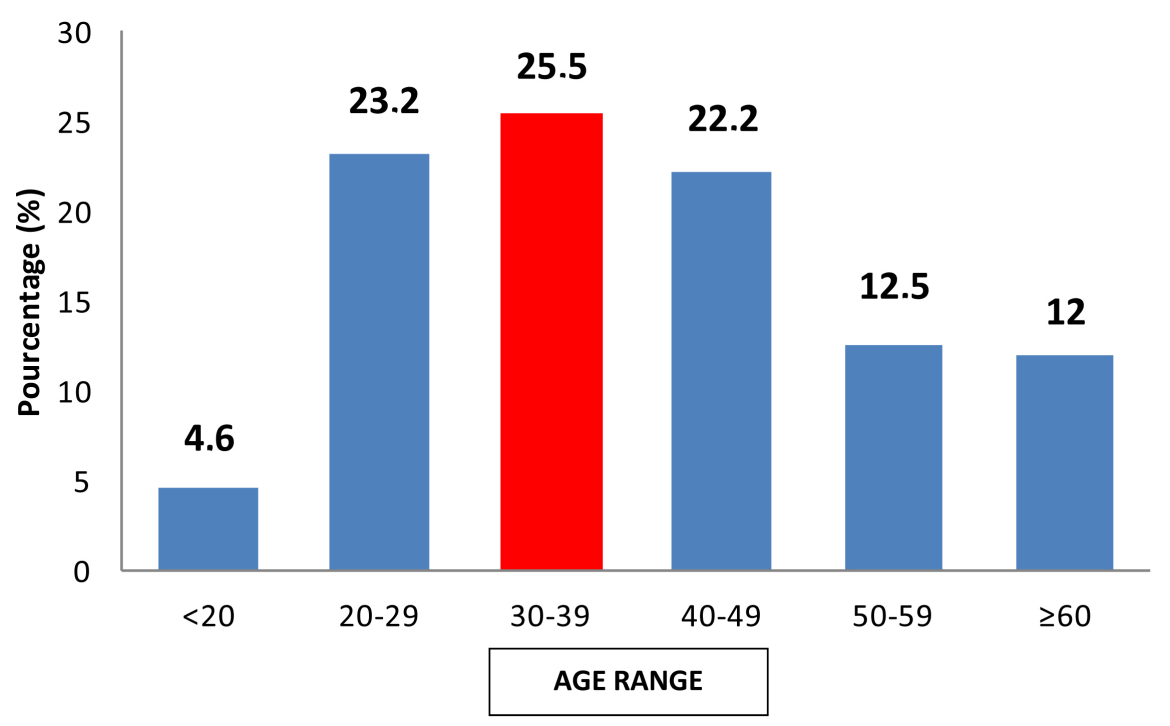

Figure 1. Distribution of study population by age.

the average age was $36 \pm 12.41$ with extremes ranging from 20 to 63 years. Hepatitis B virus DNA was detected in $83.8 \%$ (151/180) of patients with HbsAg. HDV RNA could be amplified and detected in $63.6 \%(14 / 22)$ of patients with anti VHD ac. Hepatitis B and Delta genotyping were performed on 32 of the 151 subjects with HBV DNA and 9 of the 22 subjects with HDV-positive RNA. Of the 32 cases with an identifiable HBV genotype, $46.9 \%(n=15)$ had the E genotype, $43.7 \%(n=14)$ had the A genotype and $9.4 \%(n=3)$ had the D genotype. Among the 9 subjects in whom the genotype of HDV could be identified, genotypes D1, D5, D8 were identically identified (1.11\% for each genotype). Genotype details are reported in Table 1.

\section{Discussion}

The high prevalence of HBsAg confirms Congo's place among countries with high HBV endemicity according to WHO [10] [11]. This rise can be explained by the absence of a policy to reduce the transmission of hepatitis viruses. Congo does not have a program to fight viral hepatitis. African studies report divergent results. Diara et al. in Mali reports a prevalence similar to ours (13.9\%) [12]. In the Democratic Republic of the Congo, Namululi et al. (2012) report a lower prevalence [13]. Methodological approaches can explain the differences in our study, the seroprevalence of the anti-HDV antibody is $12.2 \%$. This prevalence is low compared to those reported in the subregion by Foupouapouognigni et al. (2011) and Torimiro et al. (2014) in Cameroon which reports respectively $17.6 \%$ and $22.6 \%$ [14] [15]. These high prevalences could be explained by selection bias in patient recruitment. Indeed, in the above-mentioned works, these were hospital and non-general populations as in our work. But our prevalence remains much higher than that reported by Sawadogo et al. (2016) in Bobo-Dioulasso, Burkina Faso, West Africa, which reports a prevalence of 3.4\% of the hepatitis delta virus [16]. Gomaa et al. (2013) in Egypt in the Maghreb reports a rate of 4.7\% 
Table 1. Distribution of HBV and HDV genotypes.

\begin{tabular}{cccc}
\hline & Virus & Numbers & Percentages (\%) \\
\hline \multirow{2}{*}{ Genotypes VHB } & E & 15 & 46.9 \\
& A & 14 & 43.7 \\
D & 3 & 9.4 \\
Genotypes VHD & D1 & 1 & 11.1 \\
& D8 & 1 & 11.1 \\
& D5 & 1 & 11.1 \\
& Indetectables & 6 & 66.7 \\
\hline
\end{tabular}

[17]. The difference would be related to study (blood donor) populations that are restricted and targeted in Sawadogo and Gomaa. This difference in prevalence could also be explained by the loyalty efforts of regular and occasional donors. This confirms the hypothesis that regular donors are at low risk of disease transmission through blood transfusion, insofar as they receive information about the importance of transfusion safety and they are regularly screened for each donation of blood. Vaccination and antiviral therapy B are also evidence for the low prevalence of viral hepatitis B and D in these countries [18]. Moreover, we observed that $10.8 \%$ and $10.6 \%$ of positive HBsAg and anti-HDV positive respectively, had the notion of multiplicity of sexual partners. But the difference is not as significant ( $p>0.05)$. The majority (83.8\%) of HBsAg patients have a positive PCR. This result is identical to that reported by Atipo-Ibara et al. (2015) [11]. We found 14 (63.6\%) HBsAg-positive patients out of 22 found positive for PCR, this finding highlights that serology alone is not sufficient to make the diagnosis of virus infection Hepatitis B and Delta. Genotypes D1, D5, D8 of HDV are identified in our study with the same frequency. However, Foupouagnigni et al. (2011) in Cameroon found genotypes D1, D5, D6, and D7 of HDV with a predominance of genotype D1 [14]. The genotypic diversity in our study assumes an old spread of HDV in Central Africa like Cameroon. Among the carriers of HBsAg and anti-HD Ab, there is a predominance of genotype A with a prevalence of $44.4 \%$, however, in $\mathrm{HBV}$ mono-infected individuals genotype $\mathrm{E}$ is predominant with a frequency of $46.9 \%$. Atipo-Ibara et al. (2015) corroborate this finding and report genotypes $\mathrm{A}$ and $\mathrm{E}$ in blood donors [11]. Serological analysis of HDV was based solely on the search for anti-HDV AC. This marker alone does not differentiate co-infection or superinfection with HBV. Viral markers such as anti-HBc-HBeAg, anti-HBeAb and anti-VHD IgG/IgM-like, ASAT, ALAT would be needed for differentiation. The latter could have informed us about the precise frequency of co-infection and/or superinfection of HDV in combination with HBV.

\section{Conclusion}

The results of this work emphasize that delta virus infection is a common infec- 
tion in Congo. The existence of HDV in Congo, justifies the systematic screening of the latter, before the start of treatment in patients infected with HBV, to improve the care of patients. The establishment of a program to fight against viral hepatitis would reduce the morbidity of these infections as well as their complications in the Congolese population.

\section{Conflicts of Interest}

The authors declare no conflicts of interest regarding the publication of this paper.

\section{References}

[1] Lemoine, M., Eholié, S. and Lacombe, K. (2015) Reducing Neglected Burden of Viral Hepatitis in Africa: Stratégies of the Global Approach. Journal of Hepatology, 62 , 469-476. https://doi.org/10.1016/j.jhep.2014.10.008

[2] Stockdale, A.J., Chaponda, M., Beloukas, A., Phillips, R.O., Matthews, P.C., Papadimitropoulos, A., et al. (2017) Prevalence of Hepatitis D Virus Infection in Sub-Saharan Africa: A Systematic Review and Meta-Analysis. The Lancet Global Health, 5, 992-1003. https://doi.org/10.1016/S2214-109X(17)30298-X

[3] Andernach, E.I., Leiss, L.V., Tarnagda, Z.S., Tahita, M.C., Otegbayo, J.A., Forbi, J.C., et al. (2014) Characterization of Hepatitis Delta Virus in Sub-Saharan Africa. Journal of Clinical Microbiology, 52, 1629-1636. https://doi.org/10.1128/JCM.02297-13

[4] Lunel-Fabiani, F., Mansour, W., Amar, A.O., et al. (2013) Impact of hepatitis B and Delta Virus Co-Infection on Liver Disease in Mauritania: A Cross Sectional Study. Journal of Infection, 67, 448-457. https://doi.org/10.1016/j.jinf.2013.06.008

[5] Gomaa, N.I., Metwally, L.A., Nemr, N., et al. (2013) Seroprevalence of HDV Infection in HBsAg Positive Population in Ismailia, Egypt. Egyptian Journal of Immunology, 20, 23-28.

[6] AtipoIbara, B.I., AhouiApendi, C., Atipo-Ibara, B.I., et al. (2013) Viral Hepatitis B: Knowledge, Attitudes and Practices among Health Professionals at the Hospital and University Center of Brazzaville (Congo). Ann Univ Mar Ngouabi, 14, 20-27.

[7] Ibara, J.R., Ossendza, A., Okouo, M., Deby Gassaye Ngoma Manibouana, P. and Ngaporo, I. (1999) Primary Cancers of the Liver in Congo: Hospital Study of 558 Cases. Médecine d'Afrique Noire, 46, 394-397.

[8] Stuyver, L., De Gendt, S., Van Geyt, C., et al. (2000) A New Genotype of Hepatitis B Virus: Complete Genome and Phylogenetic Relatedness. Journal of General Virology, 81, 67-74. https://doi.org/10.1099/0022-1317-81-1-67

[9] Altuğlu, I., Özacar, T. and Sertoz, R.Y. (2007) Hepatitis Delta Virus (HDV) Genotypes in Patients with Chronic Hepatitis: Molecular Epidemiology of HDV in Turkey. International Journal of Infectious Diseases, 11, 58-62. https://doi.org/10.1016/j.ijid.2005.10.012

[10] Taty Taty, R. and Yala, F. (1990) Carrier State for HBs Antigen and HBc Antibody in Brazzaville (Congo): Sero-Epidemiological Study in the Hospital and Non-Hospital Environment. Bulletin De La Societe De Pathologie Exotique, 83, 149-154.

[11] Atipo-ibara, B.I., ItouaNgaporo, N.A., DziaLepfoundzou, A., et al. (2015) Hepatitis B Virus in Congo (Brazzaville): Seroprevalence and Genetic Diversity in Blood Do- 
nors in Hyper-Endemic Areas. Journal Africain d'hépato-gastroentérologie, 9, 127-131. https://doi.org/10.1007/s12157-015-0607-7

[12] Diarra, A., Kouriba, B., Baby, M., Murphy, E. and Lefrère, J.J. (2009) HIV, HCV, HBV and Syphilis Rate of Positive Donations among Blood Donations in Mali: Lower Rates among Volunteer Blood Donors. Transfusion Clinique et Biologique, 16, 444-447. https://doi.org/10.1016/j.tracli.2009.09.004

[13] Namululi, B.A., Guerrieri, C. and Dramaix, M. (2012) Impact of Blood Donor Recruitment Mode on Seroprevalence of HIV and HBV in Bukavu, Democratic Republic of Congo. Médecine et Santé Tropicales, 22, 69-74.

[14] Foupouapouognigni, Y., Noah, D.N., Sartre, M.T. and Njouom, R. (2011) High Prevalence and Prédominance of Hepatitis Delta Virus Genotype1 Infection in Cameroun. Journal of Clinical Microbiology, 49, 1162-1164.

https://doi.org/10.1128/JCM.01822-10

[15] Torimiro, J.N., Gwladys, M., et al. (2014) Co-Infection of Hepatitis B and Hepatitis Delta Virus in Yaounde-Cameroun. British Microbiology Research Journal, 4, 1381-1391. https://doi.org/10.9734/BMRJ/2014/6894

[16] Sawadogo, A., Ouedraogo, A.S., Poda, A., Dahourou, H., Pivert, A., Ducancelle, A., et al. (2016) Seroprevalence of Hepatitis Delta Virus Infection in a Positive HbsAg Positive Carriers Donor Population in Bobo-Dioulasso. Journal Africain d'hépato-gastroentérologie, 10, 31-33. https://doi.org/10.1007/s12157-015-0646-4

[17] Gomaa, N.I., Metwally, L.A., Nemr, N., et al. (2013) Seroprevalence of HDV Infection in HBsAg Positive Population in Ismailia, Egypt. Egyptian Journal of Immunology, 20, 23-28.

[18] Goyal, A. and Murray, J.M. (2014) The Impact of Vaccination and Antiviral Therapy on Hepatitis B and Hepatitis D Epidemiology. PLoS One, 9, 17-24.

https://doi.org/10.1371/journal.pone.0110143 